\title{
Corporate Social Responsibility: Past, Present, And Success Strategy For The Future
}

Ahmad Ahmadian, Colorado State University-Pueblo, USA

Shahrzad Khosrowpour, Chapman University, USA

\begin{abstract}
Recently, scholars and managers have devoted greater attention to corporate social responsibility (CSR) and its strategic implications. With more awareness surrounding the topic it would be expected for there to be a consensus on a definition, but as of yet none has been reached. The lack of a universally accepted definition has led some to define it as a term, a concept, a process, a theory, while others simply call it an activity or set of activities (Hazlett \& Murray, 2007). CSR has been also captioned under many names. Terms such as corporate citizenship, global citizenship, corporate social responsiveness, strategic philanthropy, and even spiritual capitalism are sometimes used interchangeably, depending on the organization to use it. Often, these numerous monikers and interpretations lead to confusion amongst those intending to study or implement the practice into their business strategy.

This uncertainty on how CSR should be defined has led some academics and practitioners to believe that the concept is void of any definition. Contrary to this belief, others find that there is an overabundance of definitions; many of which are "often biased toward specific interests and thus prevent the development and implementation of the concept" (Dahlsrud, 2008). Our study focuses on the importance of CSR and why it's becoming so prevalent in any organizations. By studying the history of CSR, its many definitions, as well as its implementation methods, we attempt to suggest strategic alternatives for an effective corporate social responsibility.
\end{abstract}

Keywords: Corporate Social Responsibility; Global Citizenship; Corporate Citizenship; Implementation Methods

\section{INTRODUCTION}

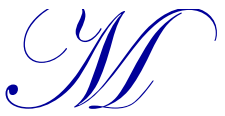

orality as we define it are one's own beliefs of right and wrong whether that is based on religion, environment, or nature is for philosophers and psychologists to determine. Ethics as we define it is a society's customs and social norms for what is and isn't acceptable behavior. These definitions while seemingly only encompassing personal issues have actually become more and more prevalent in the work force than ever before, and continue to grow every day. It is taking place in the form of CSR or corporate social responsibility. Corporate social responsibility has grown since its inception during the nineteenth century and recently has progressed at an alarming pace.

The focus of this paper is on the importance of CSR and why it's becoming so prevalent in the workforce. By studying the history of CSR and its implementation methods, we look to how CSR effects a certain industry in this case the petroleum industry. Based upon our research and findings we then attempt to suggest strategic solutions and alternatives for some of the obstacles and resistances faced when beginning CSR implementation.

A 2008 analysis of CSR definitions was conducted by Alexander Dahlsrud in an attempt to find some congruence amongst the numerous CSR definitions. In this analysis five dimensions of CSR were developed, environmental, economic, social, stakeholder and voluntariness. Definitions were gathered from various sources, including journal articles and web pages, then the content of each definition was assessed based on the five dimensions. In total, Dahlsrud (2008) found and analyzed 37 definitions, originating from 27 authors, spanning a time period from 1980 to 2003. Dahlsrud's analysis revealed that "the existing definitions are to a large degree congruent" (2008, p. 1). Of the 
37 definitions analyzed, eight of them were found to contain all five dimensions and the most frequently used dimensions were the stakeholder and social dimensions. The economic and voluntariness dimensions followed closely, while surprisingly the environment dimension was used the least in CSR definitions.

After examining the multitude of definitions available, we agree that there are many similarities amongst them and that Dahlsrud's dimensions seem to be the common theme. Thus we chose the following definition of CSR for no reason other than it was the most frequently cited and contained all of the dimensions developed by Dahlsrud,

A concept whereby companies integrate social and environmental concerns in their business operations and in their interaction with their stakeholders on a voluntary basis. (European Commission, 2011, p. 3).

Regardless of how CSR is defined, the dominant theme underlying CSR is centered on the idea of creating long-term or sustainable value amongst shareholders and stakeholders. The role of business is to create value for its shareholders but in such a way that it extends to society, resulting in a win-win situation. But, although this definition captures all of the elements of CSR, it is only an interpretation of this concept and provides no guidance as to the application or implementation of CSR.

\section{Difficulties in Implementing CSR}

It is interesting to observe that none of the definitions actually define the social responsibility of businesses, but rather describe it as a phenomenon. Many definitions call for a business to make a "commitment" to contribute to sustainable economic development, to work with society, and the need to contribute to a cleaner environment to improve quality of life without the need for coercion (WBCSD, n.d.).

In general, there are two main drivers of CSR, public policy and business strategy, but there are as many drivers as there are firms in existence. Because firms operate in and amongst society it is only natural that they be aware of the public's demands and interests. This means that businesses have greater expectations to do provide positive outcomes while mitigating the effects of negative outcomes which would affect the public. Business strategy as a driver of CSR takes into consideration costs and benefits. It can be assumed that implementing any new plan will come with costs, such as money, resources and personnel, but the unclear nature of CSR makes these costs even more risky. However, a growing number of corporate executives believe that a strategic approach to CSR creates a competitive advantage for firms. CSR can be used to differentiate a company from its competitors by prompting consumer and employee goodwill (McWilliams, Siegel, \& Wright, 2006). CSR may also be used preemptively. By successfully implementing CSR practices a firm can force their competitors to engage in CSR as well. CSR positions companies to both proactively manage risks and take advantage of opportunities.

One of the issues with identifying the types of initiatives firms should be engaging in is the number of different industries in existence today. While it may be suitable for an organization in the manufacturing industry to incorporate features into their products or manufacturing processes that reduce their negative impact on the environment, the same cannot be said about an organization in the banking industry. Another prevalent issue surrounding the implementation of CSR activities is globalization. Companies are often operating in several different geographical regions and within different industries. It is well known that "business norms and standards, regulatory frameworks, and stakeholder demand for CSR can vary substantially across nations, regions, and lines of business" (McWilliams, Siegel, \& Wright, 2006, p. 3).

Additional issues arise due to the broad scope of activities included in CSR programs which are often subject to debate. However, most programs include three key pillars: economic growth, ecological balance, and social progress (WBCSD, n.d.).

Because of the broad spectrum of CSR initiatives available to firms it is tempting to engage in all of them. Nonetheless, it would be a mistake for every company to be involved in every aspect of CSR (Hopkins, 2004). "Firms should, however, seek social and environmental strategies for which they own part of the solution." (McElhaney, 2009, p. 33). For example, Ford Motor Company's support for breast cancer research (social progress), as worthy a cause as it may be, lacks any strategic link to the company's core strength; building cars and trucks. A more suitable CSR activity 
would be to support research in alternative fuel sources (ecological balance) for the automobile industry (McElhaney, 2009).

Companies seeking to implement CSR into their strategy also need to make the distinction between strategic, altruistic and coercive CSR. Financial performance studies of companies engaged in CSR programs have distinguished a difference in effectiveness of CSR activities that are strategic, altruistic and coercive. The main difference being a competitive advantage. Strategic CSR activities (stakeholder management) can provide a company with competitive advantage that is difficult to imitate, whereas altruistic CSR (resolving social issues) is easily emulated (Hillman \& Keim, 2001). Coercive tends to be more reactive than proactive and should be avoided. For example, long-term investments in research to develop alternative energy sources would be considered a strategic CSR activity, whereas, donating money to United Way would be considered altruistic. CSR activities that provide longer-term results and benefit a larger group of stakeholders are considered relational rather than transactional (Hillman \& Keim, 2001). Leaders who focus on a relational approach (strategic approach) to CSR are often more attuned to long-term reputation of the company and tend to reap greater benefits through customer loyalty.

So when did CSR really begin to attract attention? CSR was certainly attracting attention during Ford's time, but not enough to evoke any meaningful dialogue about the concept. It can be posited that the social movements of the 1960s were what really got the ball rolling. Some of the key movements that influenced CSR were the "civil rights, women's rights, consumers' rights and the environmental movement" (Carroll \& Shabana 2010, p. 87). During this time "citizens were distrustful of their government, businesses and the undefined "establishment"."(Hopkins, 2004, p. 4). People were simultaneously realizing the importance of human rights and the need to preserve the fragile ecology of the planet. The foundation of CSR was being established by the people and ideas involved in these movements. Businesses could no longer ignore the social changes and pressure to adopt CSR perspectives, practices and policies (Carroll \& Shabana, 2010).

The 21 st century has already bore witness to many changes in CSR thinking and practice. Partially fueled by the WorldCom and Enron scandals, as well as changing societal values the early 2000s experienced an increased demand for companies to be on the right side of social justice. CSR has also received a great deal of international attention. In 2007 at the G8 Summit, the world's G8 leaders "committed their countries to promoting and strengthening corporate and other forms of social responsibility as one of four priority areas for action, through internationally agreed corporate social responsibility and labor standards" (Horrigan, 2007, p. 90). While the debate for and against CSR continues amongst academics, the reality today is that there is a growing "expectation that corporations will be significant players and models" ("The evolution of corporate," 2014).

It is also important to note that in the first half of this century there have been more than a few organizations that have demonstrated poor judgment and a lack of CSR know how. As mentioned earlier, the scandals involving WorldCom and Enron along with Arthur Andersen fueled the public's mistrust of big business. Then in 2008 the financial and mortgage crisis, which wreaked havoc on the entire world, further intensified the need for corporations to take responsibility for their actions. And in 2010 the Deepwater Horizon catastrophe in the Gulf of Mexico was a stark reminder of the impact that certain industries, namely oil, gas, and chemical industries, have on the environment and society as a whole. These are just some of the reminders of why CSR has become such an important topic in today's business environment. If nothing else, it is a way for businesses to self-regulate and be cognizant of the fact that they have a responsibility to "minimize any negative impact and maximize any positive impacts while adhering to sound financial and operation practices" ("The evolution of corporate," 2014).

To demonstrate the level of importance CSR has achieved in the past few years, the Reputation Institute has published a study that ranks companies based on how they are perceived to deliver CSR. This study is called the "Global CSR Rep Trak 100"and it measures 100 of the most highly regarded companies across 15 countries. For the 2013 study, 100,000 interviews were done across 15 markets, which included parts of Europe, the Asian Pacific, North America, and Latin America (Reputation Institute, 2013). From this study we are able to take a look at which companies were in the top three and also explain why.

Microsoft came in first place on their study for the second year in a row. Microsoft was able to do this by giving more than $900 \mathrm{~m}$ in cash and software to nonprofits and was able to reduce their carbon emissions (O'Reilly, 2013). The 
Walt Disney Company was able to come in second with their concentration on the environment, community, and promoting volunteering (http://www.businessreviewusa.com/leadership/3827/The-Walt-Disney-Company-A-Leader -In-Corporate-Social-Responsibility). Google came in third due to the perception consumers have of there working environment. Over half of the consumers that were interviewed in the study agreed that Google treats their workers fairly and therefore an attractive place to work ("Consumers give Microsoft," 2013). Another study was done in 2013 by the Wall Street Journal that ranked 60 companies based on CSR. This study was able to show which companies were shown to have the worst CSR and why. The companies with the lowest CSR rating were AIG, Goldman sack, and Halliburton (10 companies, 2013).

\section{Corporate Social Responsibility in the Petroleum Industry}

As stated earlier corporate social responsibility (CSR) has been interpreted differently in many respects, and has had a varied meaning from differing regions, decades, and even industries. Specifically, within the petroleum industry CSR has become a main driving force that studies have shown to be invaluable when looking at the performance of petroleum companies.

With CSR being used in for $90 \%$ of fortune 500 companies (Parast \& Adams, 2012) it is a trend that has been growing rapidly since its inception and that has not excluded the petroleum industry. The fact that many companies involved with the petroleum industry make up much of the fortune 500 companies (83 in 2014) speaks to how important CSR has become for the industry. Looking at the petroleum industry in particular, CSR takes on somewhat of its own definition. A definition that involves quality management as well as benchmarking, the reasons for which this definition has evolved become more apparent as we look deeper at the CSR studies performed inside the industry. The differing definitions of CSR all in some way refer to the ability of the organization to embrace practices that address the well-being of their workforce as well the community and the society (Castka \& Balzarova, 2008).

Studies in the past have shown conflicting results when looking at the impact of CSR on a firm's performance. Some studies have shown CSR to have a positive effect while others have shown to have a negative effect. This conflict is believed to have derived from inadequate/outdated measuring methods when evaluating a firm's so called "performance". The majority of previous studies that find CSR to have a negative impact on a firm's performance used the method of strictly measuring bottom line profitability in the short run for which CSR was implemented. This opposed the profitability standards that have come to arise with time, and those are the firm's market value (i.e. the conceptual value to the public). Market value has been shown to influence a company's future growth prospects as well as sustained profitability (Luo \& Bhattacharya, 2006). Studies from the years 1997, 2000, 2002, 2003, 2005, and 2009 have shown CSR to have a positive effect on preferences of customers, reputation, investors, financial analysts, stakeholders and job applicants (Parast \& Adams, 2012). All of these external factors that are not accounted for in bottom-line profitability matrices.

According to Castka and Balzarova (2008) the implementation of CSR arises from two differing perspectives. The first being the efficiency perspective (i.e. improving performance) and the institutional perspective (i.e. influenced by social pressures). The first perspective is where quality management ties into CSR. According to Corbett and Kirsch (2001) CSR follows the same developmental and trajectory path as other quality management practices. This allows for the definition of the company's "customer" to broaden and extend to the surrounding society as well as community. The expansion redefines the company's priorities from shareholders to stakeholders, which further reinforces the point that previous studies that examined CSR's impact without accounting for stakeholders used incorrect measuring variables.

The institutional theory on the other hand advocates the premise that CSR implementation does not stem solely from pressure to improve profitability, but rather from other social pressures, such as; those arising from the local government, the industrial regulations, or impacted citizens. From these two theories, three motives for a company to evidently implement CSR arise. They are as follows; the strategic approach, altruistic approach, and coercive approach.

As the name implies the strategic approach is mainly concerned with the corporate strategy, with which the petroleum industry is usually focused on shareholders. Using CSR for good PR can provide a competitive advantage and be a 
key area for using differentiation when competing in a saturated market. The altruistic approach states that the main reasoning for a company's implementation of CSR is a sense of moral duty. This implementation reasoning does not usually arise from a beneficial financial perspective making approval from top management difficult, which as we'll discuss later is a key factor for successful CSR. Finally, the coercive approach states that CSR implementation arises from pressures of groups existing directly outside of the corporation. This refers to activists, consumers, and governmental agencies. Each of these approaches has differing priorities on the main objectives that CSR helps to satisfy (McWilliams, Siegel, \& Wright, 2006).

When analyzing where CSR holds its greatest impact three areas arise far and above the rest. Those are: economic, environmental, and social objectives. These objectives are satisfied through the practices of CSR argue some researchers. Through scanning the environment and monitoring the performance of other dominant institutions in the industry organizational performance could be improved (Parast \& Adams, 2012). This point segways into a key fundamental element for effective CSR and that is benchmarking.

Benchmarking allows the company practicing CSR to not only evaluate how socially responsible the company is becoming from period to period, but it also allows for comparisons against other socially responsible corporations. By comparing the results of a company's CSR to those of competitors in the industry a company can then determine who is the most socially responsible and emulate their practices or better yet improve up on them. Finally benchmarking helps to serve the purpose of convincing top management to support or continue to support CSR initiatives. As mentioned earlier in the paper, using conventional outdated methods of performance measurements inadequately describes the positive impact that CSR can have on a corporation. In the dynamic business climate of today's industry's measurement tools need to adapt and progress to suit that of the procedures they are evaluating. Benchmarking within the petroleum industry can prove problematic though. With little transparency in the industry and a general lack of shared knowledge between major companies, performance comparisons in areas excluding direct financial performance can be hard to come by.

The petroleum industry has a great economical influence on the U.S as a whole and as such the concern over the industries implementation of CSR should be paramount. Middle Eastern oil accounts for 17\% of the U.S imported oil, the U.S petroleum industry supports more than 9.2 million jobs and comprises $7.5 \%$ of the U.S GDP. Forecasts suggest that in a twenty five year period there will be 9.6 trillion dollars spent on investments in the petroleum industry. This figure is nothing to trifle at and as such implicates us (as effected citizens) to examine and monitor the CSR of the industry. A few more unique characteristics that differentiate the petroleum industry are: the suppliers, raw materials, high transportation costs, production process, and sources of profitability. As far as suppliers go, there is a limited number, creating a seller's market. The raw materials the price of crude oil fluctuates constantly in comparison to other industries. The transportation costs are high in the petroleum industry making up about $20 \%$ of the production costs (Parast \& Adams, 2012). Since the petroleum industry uses constant operations it greatly benefits from economies of scale and therefore has very low production costs. This also creates very rigid procedures that are very costly to deviate or change leaving little room for deviation. The sources of profitability for the industry arise from efficiencies and cost reductions in procedures and transportation. Also within the petroleum industry, profitability of oil and gas companies is heavily influenced by external variables (e.g. political and economic forces) which also imply that top management plays a strong role in performance for this type of industry. These unique characteristics while helping to prove that CSR can prove vital in even capital intensive markets, it should also be noted that due to these characteristics the findings and methods of studies for CSR and its impact on the petroleum industry are not universal. Each industry has its own specific characteristics and as such CSR should be applied accordingly.

In conclusion empirical findings show that investors are more likely to invest in firms that are committed to socially responsible practices (Hoje Jo, 2003). Just as well the effect of corporate social responsibility goes beyond improving customer satisfaction and loyalty it has the capability to generate "more capital" which could lead to improving employee morale, productivity and efficiency (Godfrey, 2005). For concluding results a study was done on the effects of CSR in the petroleum industry of Iran (which has the second largest oil and gas reserves in the world) and the results were somewhat expected. The link between CSR and internal quality results has been hypothesized to have a strong relationship in the petroleum industry. This is due to the fact that improving quality (in theory) allows petroleum firms to charge higher prices therefore increasing profitability. In addition, improving internal quality leads to a reduction in waste, higher efficiency, and an increase in the return on assets which in the long run benefits profitability 
(Parast \& Adams, 2012). This quality improvement also leads to creates customer satisfaction, leading to greater customer loyalty which in turn boosts sales and profitability. These benefits for the petroleum are key in staying ahead of the intense cost savings competition, making CSR all the more valuable for the industry.

The results of the study were as the researchers theorized, and a strong correlation was show between internal quality results. Strikingly though the researchers also found a weak, but negative nonetheless, correlation between CSR and external quality results. This correlation is speculated to have been the cause for why some older studies of CSR showed a negative impact on firm profitability, especially if the industry was heavily dependent upon external quality. Luo and Bhattacharya (2006) in their studies found that customer satisfaction was largely reason why CSR had a positive impact on firm performance. They further suggested that CSR had the greatest positive effect on profitability in industries that had high levels of innovation, high cost products, and a long term customer base.

\section{General Pros and Cons of Corporate Social Responsibility}

Overall, there are many different advantages to Corporate Social Responsibility and many of them pertain to a certain industry. The advantages that we will be concentrating on are innovation, brand differentiation, and increased value to the company. These three advantages can be applied to all different types of industries (J Epstein-Reeves, 2012).

Innovation is a change that a company make for many different reasons. When we talk about innovation and CSR we are usually talking about changes that are being made to products to benefit the community. For example, Unilever developed a hair conditioner that uses less water in the production process of their product (J Epstein-Reeves, 2012). Making this change, it helps out the environment by using less water and reduced transportation cost for Unilever Corporation.

Brand differentiation is used by companies to distinguish them from their competitors. Since CSR has become more common is has become harder for companies to distinguish themselves from their competitors. An example of two companies trying to differentiate their brands are Coca Cola and Pepsi. They both are researching on how to lower their water usages and also have both be able to water bottles that are made from sustainable packaging (J EpsteinReeves, 2012). Although brand differentiation maybe difficult to achieve when it comes to CSR, it is better to try than to be left behind by your competitor.

The value a customer or a potential investor places on a company does not always depend on what is on their balance sheet. People look at the reputation of a company and how it contributes to society when taking into account the value a company actually has. CSR helps add to this value because it shows the company's accountability and makes it more transparent (Kielmas, n.d.). This helps people trust the company that they are buying their products from or helps determine whether they would like to do business with them or not. A good example of this is Microsoft. They were ranked number one on Global CSR Rep Trak 100 study (Reputation Institute, 2013). "Microsoft gave more than $\$ 900 \mathrm{~m}$ in cash and software to nonprofits worldwide last year, reduced its carbon emissions by 30 per cent per unit of revenue compared with 2007 and made the company's biggest ever investment in overall employee compensation" according to Market Week (O'Reilly, 2013). With all of these contributions both financially and for the environment, consumers view Microsoft to have a higher value than others.

\section{Pros of CSR in the Petroleum Industry}

For the petroleum industry engaging in corporate social responsibility (CSR) has its advantages and disadvantages, which can have a huge impact on operations. Abiding by legal regulations and ensuring environmental sustainability can decrease overall risk, reduce regulatory pressure from the government, and benefit long-term operations in the petroleum industry. However, doing so often comes at a cost to the company.

When entering the oil industry companies are choosing to accept the immense risk that is involved with the industry. Because of the negative stigma and effect that oil operations can have on the environment, reputation and legal risks are often associated with the industry. 
In terms of legality, CSR applies to areas such as: proper waste management, environmental sustainability, pollution prevention, proper reporting etc. Companies are expected (by both the public and government) to abide by all legal regulations as well as enhance environmental sustainability. A company that emphasizes CSR in its corporate strategy reduces the overall risk that is undertaken when entering this type of industry. The legal risks diminish when laws and regulations are understood, and proper procedures are implemented in all daily acivities. This minimizes the possibility of: law suits, shutdowns, and liability claims that can be extremely damaging to a company.

The application of CSR also helps to reduce the amount of reputation risk surrounding the petroleum industry. Management of brand image is a largely in part from the company's effectiveness in marketing and public relations. A negative reputation (i.e. lack of credibility) can be detrimental in regards to consumer trust, and business-to-business networking. A competitive advantage of oil companies emphasizing CSR is maintaining a positive reputation in society. The BP and ExxonMobil oil spills are a good representation that one mistake in regards to environmental sustainability can stain a company's image for a very long time.

Society has increased its efforts to improve the environment; as a result unflattering instances such as the BP oil spill are highlighted throughout media. Due to the advancement of communication technology, the combination of transparency in the oil industry and the constant connection of consumers allow all aspects and operations to be observed. CSR helps to reduce the possibility of making mistakes, such as oil spills, that are then a part of a company's image for the ensuing years.

Another advantage of CSR is that it reduces regulatory pressure from the government. If oil companies do not take responsibility and therefore initiate maintaining the environment, society then looks to the government to regulate the companies. Restrictions and procedures put into place by the government restrain the innovation and operation of the industry. Since CSR includes the practice of self-regulation, it relieves the pressure that government's burden in order to regulate the industry. CSR allows companies to have more impact on, and design in, the operations, as well as the manner in which they report and maintain environmental sustainability (Spence, 2011). In essence oil companies can protect the power and control they have within their company and industry by maintaining a high level of corporate social responsibility.

Lastly the final advantage involves the benefits that are accumulated over a long period of time. It is very important for companies to not only focus on the immediate advantages of CSR in the present, but also the impact it will have on business in the distant future. In regards to the petroleum industry; CSR involves maintaining a healthy living environment, and possibly the investment in the condition of the geographic area of operations. In many cases oil companies are extracting and conducting business in other parts of the world, including underdeveloped countries. By conducting ethical practices the company enhances the environment in which their workers or future workers will be contributing. Employees typically prefer to work in a society with minimal pollution and healthy working conditions, therefore practicing CSR will attract and better retain good employees.

Being socially responsible also nourishes business-to-business networking. Reporting on environmental aspects reduces the trust deficit and the concern of company stakeholders (Guenther, Hoppe, \& Poser, 2007). Within a supply chain, it is important to maintain trustworthy and credible relationships with other companies. People prefer to work with companies that have a positive reputation, for many reasons not excluding; in order to maintain their own positive reputation. Losing the business of a customer, supplier, or partner can have a destructive impact on the long-term performance of an oil company. This is why CSR presents a critical advantage for oil companies. CSR emphasizes development of a healthy workforce and the protection of trust amongst business partners. Meaning long-term benefits of CSR within the operations of the oil industry are practically infinite.

The general benefits of corporate social responsibility previously discussed, are only a few of the many; in regards to the functioning of companies within the oil industry. This industry has many risks that have a great impact on the: performance, value, and future of a company. The constant implementation of CSR will reduce those inevitable risks, allow greater control for companies (by relieving governmental pressure), and also benefit the future growth of the industry. 


\section{Cons of CSR in the Petroleum Industry}

Although there are seemingly endless amounts of advantages stemming from corporate social responsibility in the oil industry, there are also some disadvantages. CSR demands time and resource consumption that may be difficult for companies to allocate. The two disadvantages being discussed in this section are the difficulty of CSR implementation and the obligation of oil industries to engage in CSR in multiple countries.

Within the petroleum industry are several obstacles that must be overcome when attempting to implement CSR. Knowledge is essential to the successful of implementation of CSR. The variations of regulations and laws within a variety of states and countries must be understood when conducting business. This involves the company's time and allocation of resources for training, and updating systems for changing regulations. Companies may also create positions that are primarily focused on CSR and its maintenance. Problems in this area arise due to smaller companies not having the time or capital for specific CSR departments, and larger companies having difficulty communicating and integrating CSR procedures. Within CSR there are mandated guidelines for the reporting of CSR regulations that are in place. This adds to the difficulty of implementing CSR because reporting should be consistent across an organization; which demands an integrated approach. Larger companies will also require more capital (compared to smaller firms) for implementing training and procedures, having an impact on the earnings for its shareholders. Even though there are benefits to CSR they are long-term benefits that will require substantial early investments in order to succeed.

Operation processes will require more time allocation for those involved in the engagement of CSR, because CSR processes require more reporting and more strategic planning. Management must not only think about what their next steps are but also the future impact those steps will have on society. Planning will likely have to become an extended process to ensure that regulations are abided by and that mistakes will not take place. The reporting of these steps will also require a substantial amount of time devoted to the process. This is the main argument against CSR implementation, and why many companies devoutly focused on solely the bottom line reject CSR programs. It requires that companies to not only put extra effort into training, but reporting the activities of the company to all stakeholders. Corporate social responsibility consumes extra time and money of the companies that seek to implement it, which creates obstacles and early disadvantages that must be endured.

The practicing of CSR policies for global oil companies presents another complication in and of its self, one that requires strong strategic planning and international knowledge. The presence of diverse beliefs within other countries makes it very difficult for oil companies to implement corporate social responsibility and ethical practices across the organization. For example, some countries encourage child labor and abide by lesser working condition than those enforced by the company's home country. This raises the dilemma of whether or not to be ethical in regards to the company's home country's standards, or respect the host country's standards. There is in infinite amount of gray area when it comes to international business, making it hard for oil companies to undertake CSR when operating in several countries, due to there being more than one standard.

Along with the difficulty of implementation, another disadvantage for oil companies is the obligation to take care of; not only the geographic domain of its home country, but also its host countries. Most countries expect companies (particularly in the oil industry) that are based within them to operate their foreign extensions to the same level of CSR that they follow in their home country. The bottom-line is about improving the environment, regardless of home or host country. Oil companies must abide by regulations of several different governments and in doing so endure different kinds of political risk. Causing CSR to become difficult to maintain in the oil industry because it must be implemented in all geographic areas of operations; this is a huge disadvantage because it requires more money, adaptability, and knowledge.

Citizens of several underdeveloped countries consider their respective governments to be corrupt. Research shows that companies who partner with these governments gain a negative reputation with the residents of that country, and possibly in its home country as well. In developing countries legal standards and regulations may be weak or nonexistent. When Royal Dutch Shell began looking for oil in Nigeria in the 1950s the royalties paid to the country went to its corrupt government rather to its people. This created a repugnant reputation for the company. Once Shell recognized its social impact and its contamination it began to put efforts into place to rectify its negative impact on its 
host country. By the time Shell initiated implementation of CSR their reputation had already landed in an unrecoverable state, and its operations in Nigeria were greatly affected (Spence, 2011).

The Nigerian people began protesting vigorously and sometimes violently, which sparked an onslaught of bad PR for Shell. Human rights organizations fought to protest Shell and families of those affected by Shell's malpractices eventually received $\$ 15.5$ billion in settlements during 2009. Because of the absence of federal governments, officials who could enforce regulations on multinational oil companies become the targets for the anger and grievances of the host country's residents (Rwabizambuga, 2007). This example shows that companies need not only maintain corporate social responsibility in their home country, but also in the countries within which they operate. This practice continues to require more of the company's resources (as stated earlier), potentially showing one of the major disadvantages that CSR presents, particularly for global companies.

The disadvantages of corporate social responsibility are primarily centered around its' implementation. The implementation requires research, time, resources, and challenges companies ethically. There is a lot of time that must go into strategic planning as for how to undertake global social responsibility. These are major disadvantages of oil companies engaging in CSR, and must be weighed appropriately when looking to the advantages of CSR while also deciding whether or not CSR implementation practices are in a company's best interest.

\section{CONCLUSION: SUCCESS STRATEGIES FOR CSR IMPLEMENTATION}

It is apparent that implementation of CSR is often extremely difficult. It is challenging to balance being socially responsible and keeping stockholders happy (i.e. maintaining the bottom line). If a company is investing in CSR it is going to initially affect stockholders' earnings, which will not make them very happy. Another obstacle to overcome when attempting to implement CSR is determining an ethical standard when operating internationally. Putting CSR processes into effect is cumbersome for companies, but using strategic planning can allow a smoother transition into being a socially responsible corporation. Some of the strategic planning success factors are very relevant to CSR implementation. Avoiding number games, anticipating the future, contingency planning, and involving top management are all essential to this demanding process.

CSR must be implemented and carried out in order for a company to attain financial benefits. Avoiding the number game is important because although money is being allocated to environmentally sustainable processes without financial gain, the benefits of CSR will pay back the company in time. CSR may improve brand reputation and customer loyalty now that consumers have become more environmentally conscious. It is also shown that a mistake or scandal that a company is involved in has a reduced negative effect on a company's reputation if the company is known for emphasizing corporate social responsibility (Minor \& Morgan, 2011). Numbers do not always immediately show a boost in the way consumers view a brand, but this boost can have a big impact on the bottom line in the future.

Anticipating the future is vital in any type of strategic plan. When planning the implementation of CSR it is important to take into consideration the changes that the future may hold. The macro external environment is very dynamic and constantly changing, which also makes staying flexible necessary when attempting to apply CSR to company operations. The future can present an array of opportunities and threats to a company and a more prepared company will prosper more than an unprepared.

Contingency planning involves making a plan along with other plans designed to be put into effect if alternative events occur. Situations change throughout time and the expectations of CSR do as well. In an industry such as the oil industry there are several situations that can occur unexpectedly that may induce environment, social, and government pressures such as an oil spill or a leak of harmful waste. Contingency planning allows a company to be prepared for such situations or instances to occur and will make implementation and the sustainability of CSR more successful.

The last and plausibly most important key factor to successfully creating a strategic plan for CSR implementation is the involvement of top management. CSR may not be most favorable in the eyes of the shareholders or top management, which is why it is so essential to gain their support. The implementation of CSR will typically start with top management and their attitude heavily affects the message being received by employees and stakeholders. The process of engaging in CSR as a corporation will be easier with top management's approval and input. These are the 
people that know essentially the most about operations and will be able relay information about the ongoing process. Remembering this in strategic planning allows effective communication with all stakeholders and in this case communication of the future benefits of CSR. As long as top management is on board with corporate social responsibility, this particular development of the company should be received well by employees and stakeholders.

\section{AUTHOR BIOGRAPHIES}

Ahmad Ahmadian, Ph.D. is professor of management at Colorado State University-Pueblo. His areas of expertise are in international business and global strategic management. He has over 30 years of experience in teaching, research and consulting. His research interests are the comparative study of American, Japanese, and European strategic management approaches, corporate social responsibilities, and organizational change.

E-mail: ahmad.ahmadian@csupueblo.edu

Shahrzad Khosrowpour, MLS, BS (Engineering) is a librarian at Chapman University, Orange, California. She has over 14 years of experience in librarianship focused in academic libraries and information management. She considers library science a multidisciplinary field that can be applied to different disciplines and research areas. In her library career, she has taken advantage of this fact and has shown research interests in science, engineering, business, world languages and cultures, and international studies. E-mail: shahrza@chapman.edu

\section{REFERENCES}

10 companies with the worst reputations. (2013, March 5). [slide show]. Marketwatch. Retrieved from http://www.marketwatch.com/story/10-companies-with-the-worst-reputations-2013-03-05

Carroll, A. B., \& Shabana, K. M. (2010). The business case for corporate social responsibility: A review of concepts, research and practice. International Journal of Management Reviews, 12, 85-105. doi:10.1111/j.1468-2370.2009.00275.x

Castka, P., \& Balzarova, M.A. (2008). ISO 26000 and supply chains-on the diffusion of the social responsibility standard, International Journal of Production Economics, 111(2), 274-286. Retrieved from http://dx.doi.org/10.1016/j.ijpe.2006.10.017

Consumers give Microsoft, Disney, BMW, Google highest marks for the CSR performance. (2013, October 4). Sustainable Brands. Retrieved from http://www.sustainablebrands.com/news_and_views/communications/consumers-givemicrosoft-disney-bmw-google-highest-marks-csr-performan

Corbett, C. J., \& Kirsch, D.A. (2001). International diffusion of ISO 14000 certification. Production and Operations Management, 10(3), 327-342. Retrieved from http://onlinelibrary.wiley.com/doi/10.1111/j.19375956.2001.tb00378.x/epdf

Dahlsrud, A. (2008). How corporate social responsibility is defined: An analysis of 37 definitions. Corporate Social Responsibility and Environmental Management, 15(1), 1-13. doi:10.1002/csr.132

European Commission. (2011, October 25). A renewed EU strategy 2011-2014 for corporate social responsibility. Retrieved from http://eur-lex.europa.eu/LexUriServ/LexUriServ.do?uri=COM:2011:0681:FIN:en:PDF

The evolution of corporate social responsibility (CSR) and what it means for today's associations. (2014, December 14). Bostrom Solutions for Success. Retrieved from http://www.bostrom.com/the-evolution-of-corporate-social-responsibility-csrand-what-it-means-for-todays-associations/

Godfrey, P.C. (2005). The relationship between corporate philanthropy and shareholder wealth: A risk management perspective. Academy of Management Review, 30(4), 777-798. Retrieved from http://www.jstor.org/stable/20159168

Guenther, E., Hoppe, H., \& Poser, C. (2007). Environmental corporate social responsibility of firms in the mining and oil and gas industries: Current status quo of reporting following GRI guidelines. Greener Management International, 53, 7-25. Retrieved from https://eds.b.ebscohost.com/ehost/pdfviewer/pdfviewer?sid=f145f346-9a85-4570-8cccbba93b8c0be8\%40sessionmgr103\&vid=3\&hid=108

Hazlett, S., \& Murray, L. (2007). From quality management to socially responsible organizations: The case for CSR. International Journal of Quality \& Reliability Management, 24(7), 669-682. doi: 10.1108/02656710710774665

Hillman, A. J., \& Keim, G. D. (2001). Shareholder value, stakeholder management, and social issues: What's the bottom line? Strategic Management Journal, 22(2), 125-139.

Hoje Jo, J. (2003). Financial analysts, firm quality, and social responsibility. The Journal of Behavioral Finance, 4(3), $172-183$. Retrieved from http://dx.doi.org/10.1207/S15427579JPFM0403_6

Hopkins, Michael. (2004). Corporate social responsibility: An issues paper, working paper no. 27. Geneva, CH: International Labour Organization. Retrieved from https://ssrn.com/abstract=908181

Horrigan, B. (2007). $21^{\text {st }}$ century corporate social responsibility trends: An emerging comparative body of law and regulation on corporate responsibility, governance, and sustainability. Macquirie Journal of Business Law, 4, 85-121. Retrieved from http://unpan1.un.org/intradoc/groups/public/documents/apcity/unpan033581.pdf

Copyright by author(s); $\underline{\text { CC-BY }}$ 
Kielmas, M. (n.d.). Pros \& cons of corporate social responsibility. Small Business. Retrieved from http://smallbusiness.chron.com/pros-cons-corporate-social-responsibility-56247.html

Luo, X., \& Bhattacharya, C.B. (2006). Corporate social responsibility, customer satisfaction, and market value. Journal of Marketing, 70(4), 1-18. doi: http://dx.doi.org/10.1509/jmkg.70.4.1

McElhaney, K. (2009). A strategic approach to corporate social responsibility. Leader to Leader, 2009(52), 30-36. doi: $10.1002 / 1 \mathrm{t} 1.327$

McWilliams, A., Siegel, D. S., \& Wright, P. M. (2006). Corporate social responsibility: Strategic implications. Journal of Management Studies, 43(1), 1-18. doi:10.1111/j.1467-6486.2006.00580.x

Minor, D., \& Morgan, J. (2011). CSR as reputation insurance: Primum non nocere. California Management Review, 53(3), 4059. Retrieved from http://nrs.harvard.edu/urn-3:HUL.InstRepos:22836595

O'reilly, L. (2013). Microsoft has best global reputation. Marketing Week. Retrieved from https://www.marketingweek.com/2013/10/03/microsoft-has-best-global-csr-reputation/

Parast, M., \& Adams, S. G. (2012). Corporate social responsibility, benchmarking, and organizational performance in the petroleum industry: A quality management perspective. International Journal of Production Economics, 139(2), 447458. doi:10.1016/j.ijpe.2011.11.033

Reputation Institute. (2013). Global CSR RepTrak® 100: Top line report. Retrieved from https://www.rankingthebrands.com/PDF/CSR\%20RepTrak\%20100,\%202013\%20Reputation\%20Institute.pdf

Rwabizambuga, A. (2007). Negotiating corporate social responsibility policies and practices in developing countries: An examination of the experiences from the Nigerian oil sector. Business \& Society Review, 111(3), 407-430. doi: 10.1111/j.1467-8594.2007.00302.x

Spence, D.B. (2011). Corporate social responsibility in the oil and gas industry: The importance of reputational risk. ChicagoKent Law Review, 86. Retrieved from http://scholarship.kentlaw.iit.edu/cklawreview/vol86/iss1/4

WBCSD. (n.d.). Corporate social responsibility: Meeting changing expectations. Retrieved from https://growthorientedsustainableentrepreneurship.files.wordpress.com/2016/07/csr-wbcsd-csr-primer.pdf 


\section{NOTES}

